\title{
Osmussaar: the rise and fall of an island
}

\author{
Ü. Suursaar ${ }^{1} \&$ H. Tõnisson ${ }^{2}$ \\ ${ }^{1}$ Estonian Marine Institute, University of Tartu, Estonia \\ ${ }^{2}$ Institute of Ecology, Tallinn University, Estonia
}

\begin{abstract}
Changes in the natural and settlement history of Osmussaar Island are studied on the basis of hydrodynamic and geomorphic field experiments, as well as on old maps, archive material and ethnographic literature. Osmussaar is a $5 \mathrm{~km}$ long and $8 \mathrm{~m}$ high island which emerged from the Baltic Sea about 3000 years ago as a result of postglacial rebound. At present, the regional uplift is nearly balanced out by the global sea level rise and from now on projected increasing storminess and sea level acceleration will likely reduce the size of the island. The island is exposed to storms from western and northern sectors. Wind waves and sea level variations during occasional storm surges, such as the ones in 1967, 2005, and 2007, are the main hydrodynamic factors responsible for coastal changes in this part of the nearly tideless Baltic Sea. The limestone cliff on the NW part recedes approximately $9 \mathrm{~cm} / \mathrm{yr}$ and the longshore transport of gravel-pebble feeds the spits and beach ridges at the southern end. Socially, the island has undergone some highs and lows as well. In the 1930s, a community of 130 inhabited the island; in 1940 they were replaced by a Soviet military base. Nowadays, one household is permanently residing on the island but the prospects for eco-tourism are good.
\end{abstract}

Keywords: sea level rise, coastal dynamics, island community, WW2, climate change, Baltic Sea.

\section{Introduction}

By their nature, islands are well-defined and culturally more or less isolated, and therefore also fascinating, discrete units to study [1]. Although Estonia is a small country, it has a relatively long coastline and it is rich in islands. In total, there are about 1500 islands, making up $4133 \mathrm{~km}^{2}$ or $9.2 \%$ of its territory's area. Most of them comprise the West Estonian Archipelago (Fig. 1). 


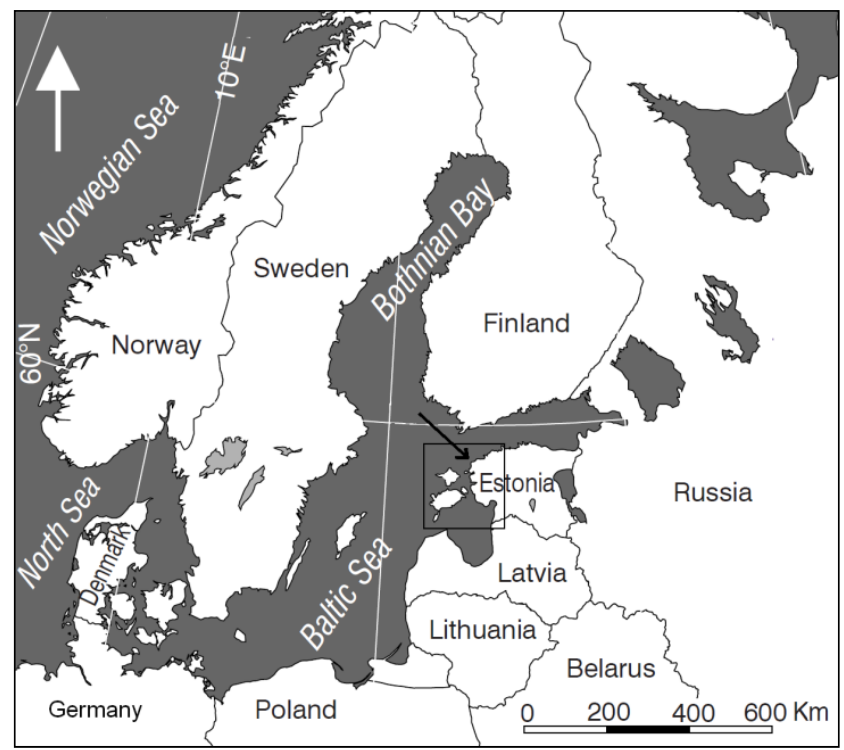

Figure 1: Map of the study area. The rectangle shows the West Estonian Archipelago and the arrow indicates Osmussaar.

Located somewhat separately in the entrance of the Gulf of Finland, Osmussaar (Odensholm in Swedish) is the 14th largest island in Estonia with an area of $4.7 \mathrm{~km}^{2}$. It is $1.3 \mathrm{~km}$ wide and $4.6 \mathrm{~km}$ long. Despite its small size, it is an island with a remarkable setting, nature and history. The island was possibly inhabited already in the Viking age. The continuous settlement of Estonian Swedes on Osmussaar, which thrived until World War II, goes back at least to the 14th century [2]. Starting from the 1940s, the fate of the island was determined by its strategic position. Military actions and coastal artillery battery shaped its landscape until the 1990s, when Estonia regained its independence. As a part of the West Estonian Archipelago Biosphere Reserve, it now draws the occasional tourists and is the focus of scientific research.

In recent years, a number of hydrological and geomorphic field studies have been conducted on the island [3,4]. Coastal geomorphic and landscape surveys have been regularly carried out since 2004 and analysis has been performed of aerial photographs and old charts dating back to 1900 . In addition, measurements of waves and currents were taken at two sides of the Osmussaar Island: at the Neugrund bank in 2009-2010 [4] and at Sundgrund in 2011. The hydrodynamic forcing data obtained both on the windward western side and the leeward eastern side were used to calibrate models, which can be applied to long-term hindcasts.

The objective of the paper is (1) to present a natural and cultural overview of the Osmussaar Island, (2) to study its areal growth and cultural developments over the last centuries, and (3) to investigate the current and possible future coastal developments in relation to temporal variations in climatological and hydrodynamic forcing conditions. 


\section{Material and methods}

\subsection{Oceanographic and meteorological data}

The study is based firstly on meteorological and sea level data from the weather and tide gauge stations which are operated by the Estonian Meteorological and Hydrological Institute (EMHI). Sea level data were obtained from the three tide gauges, located close to the Osmussaar Island: Paldiski $(37 \mathrm{~km})$, Rohuküla $(40 \mathrm{~km})$ and Ristna $(80 \mathrm{~km})$. Digitized data are available since 1950. Meteorological data for forcing the wave model were obtained from the Pakri (Paldiski) meteorological station $\left(59^{\circ} 23.3^{\prime} \mathrm{N} ; 2^{\circ} 02.4^{\prime} \mathrm{E}\right)$, located $30 \mathrm{~km}$ east of the Neugrund mooring site and $38 \mathrm{~km}$ from the Sundgrund site. The Pakri station has been operational since 1865 , but the exact position of the station on the Pakri Peninsula has changed slightly, most recently in September 2003. Digitized wind records are available since 1966.

The hydrodynamic study is based on measurements of waves and currents made using the Doppler-effect based current profiler (RDCP-600 by AADI) in

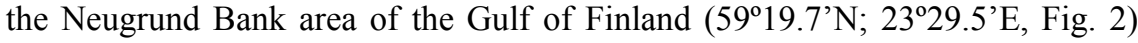
between 20 November 2009-24 April 2010. The instrument was installed on the seabed at a depth of $15 \mathrm{~m}$. At Sundgrund (59 $\left.15.2^{\prime} \mathrm{N} ; 23^{\circ} 23.7^{\prime}\right)$, the instrument was installed at a depth of $12 \mathrm{~m}$ during the period between 18 September10 November 2011. The wave data were used to calibrate a wave model using the SPM method [5], which was then applied to long-term wave hindcasts. The calibration was done by prescribing fetch distances for different wind directions with a step of $20^{\circ}$ and searching for the appropriate depth parameter [6, 7]. Based on wind data, the model calculates the parameters of significant wave height for a chosen location.

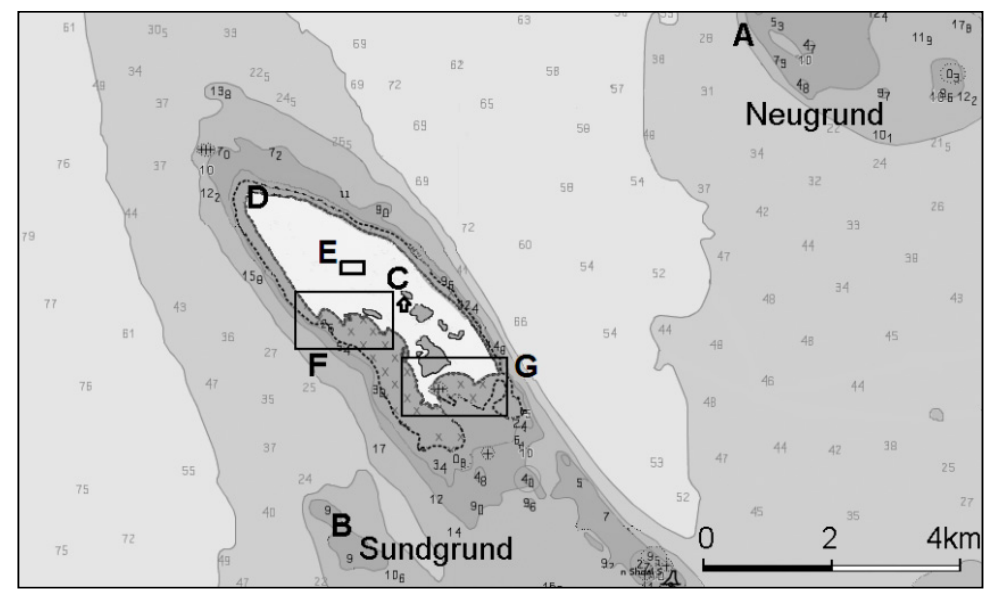

Figure 2: Bathymetric map of the Osmussaar area. The locations of the RDCP moorings at Neugrund (A), Sundgrund (B); chapel (C), lighthouse (D), village (E), coastal study areas "1" (F) and "2" (G). 


\subsection{Cartographic and geomorphic sources and data on human settlement}

Studies on recent coastal geomorphic changes are possible on the basis of old maps and various photographs, which date back to 1900. Topographic maps from the years 1900, 1935, 1939, 1947, 1961 and 1981; aerial photographs from 1987; and orthophotographs from 1998, 2005, 2008 and 2010 (pixel sizes between 25 and $100 \mathrm{~cm}$ ), were compared to analyze the geomorphology at the study sites and the changes in shoreline position. The main study areas were in the northern tip of the island (near lighthouse, Fig. 2) and at the south-western part of the island (areas "1" and "2", Fig. 2). GPS measurements and precise levelling studies were performed in 2004-2011 to assess short-term changes in shoreline position and the contours of beach ridges. From 2004 until 2010, shoreline positions were measured using hand-held Garmin devices (accurate to within $3 \mathrm{~m}$ ), and after 2010, shoreline positions were measured using a Leica DGPS GS09 (accurate to within 1-2 cm). A levelling survey was carried out to evaluate changes in volumes of coastal features using a Leica Sprinter Digital Level $180 \mathrm{M}$ and MapInfo software was used to calculate reductions in the erosion areas and increases in accumulative areas.

The history of the Estonian-Swedish community on Osmussaar can be examined through old maps, archival records and personal memoires. Primary archive material is kept in the Estonian State Archive (ERA), the Estonian History Archive (EAA), and the Estonian National Museum (ERM). Dr. Tiina Peil [2] has studied settlement history on the island by summarizing the archival data and various ethnographic material gathered from various Swedish sources.

\section{Natural history of Osmussaar island}

\subsection{Geological and oceanographic features of the island and the surrounding seas}

Geologically, Osmussaar is an approximately $1 \mathrm{~km}$ wide and $5 \mathrm{~km}$ long relict island of the Baltic Clint, overlain by a thin layer of Quaternary deposits [8], which emerged from the Baltic Sea about 3000 years ago as a result of postglacial rebound. The study area is still experiencing the isostatic land uplift with a current rate of about 2.6 to $2.8 \mathrm{~mm} / \mathrm{yr}$ [9]. This uplift rate is among the fastest in Estonia, where its influence diminishes towards SE. On the seashores, the fast uplift mainly manifests as locally decreasing sea levels (Fig. 3a-c) and growth of the "new land" (Fig. 4).

An Ordovician limestone (440 to 480 million years old) cliff up to $7 \mathrm{~m}$ high is the most characteristic feature on the northern part of the island, whereas 2 3 meter high accumulative gravel-pebble beach ridges cover the southern part. The main shore processes are erosion from the Osmussaar cliff, longshore southward transport of gravel-pebble and accumulation of material as beach ridges at the southern end of the island. Increments of the spits often rejoin the main island and several brackish-water coastal lagoons can be found behind the spits. The coastal slope is steep on the eastern side of the Osmussaar Island - the 

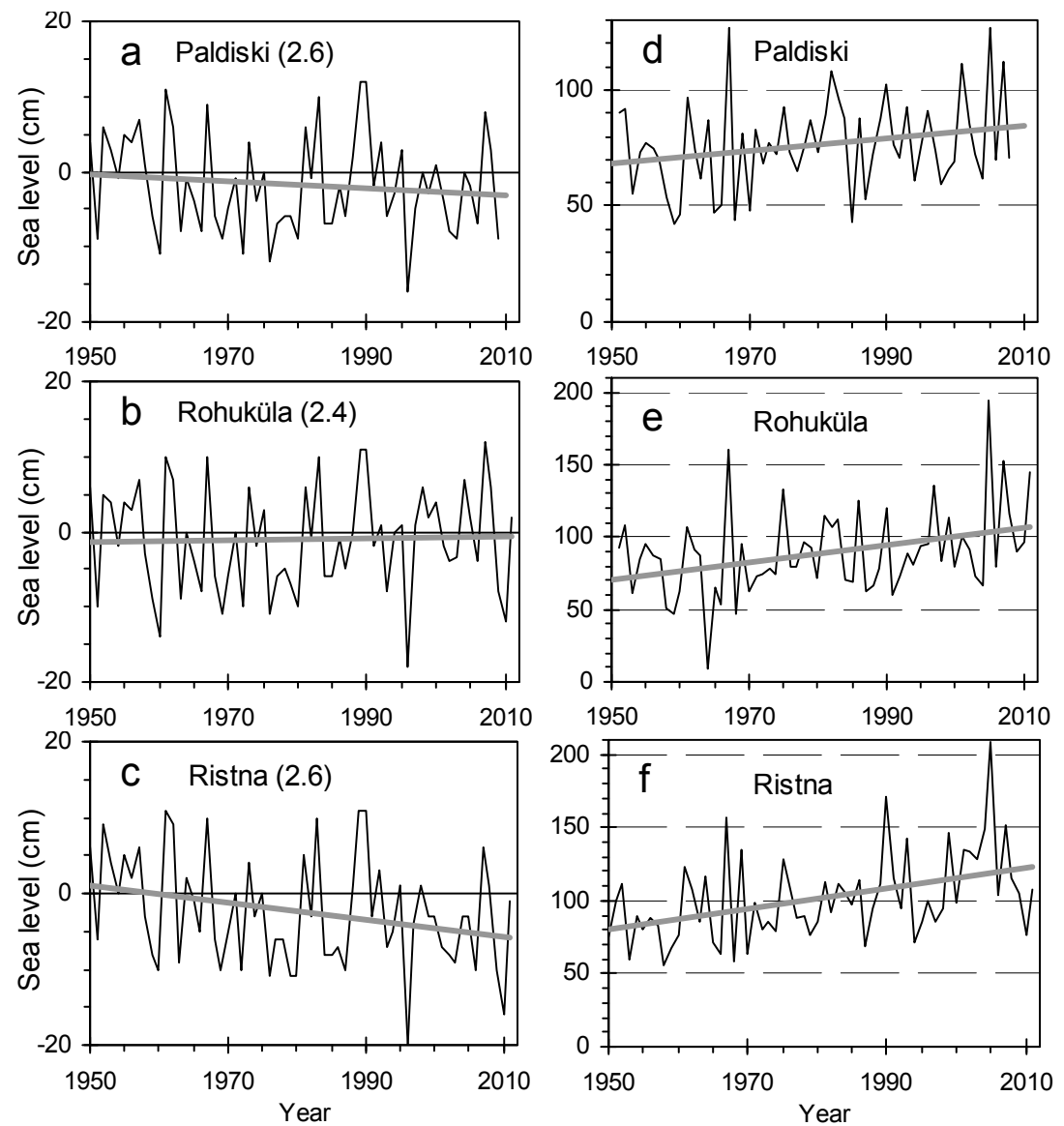

Figure 3: Variations in annual mean (a,b,c) and maximum (d,e,f) sea levels at three tide gauges close to the Osmussaar in 1950-2011. The numbers in brackets denote post-glacial land uplift rates in $\mathrm{mm} / \mathrm{yr}$.

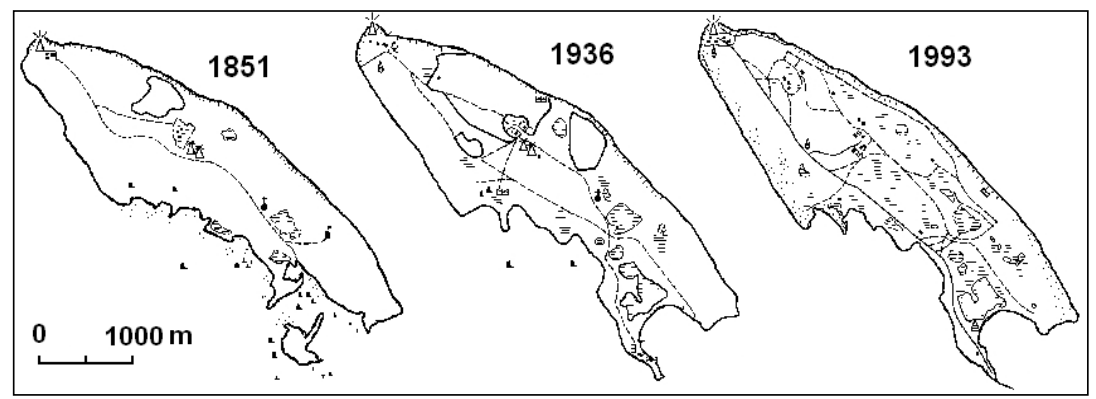

Figure 4: Changes in coastline and land use in the Osmussaar according to various maps archived in the ERA and Estonian Map Centre [2]. 
depth increases to 20 meters in less than 500 meters. The sea is very shallow (less than 5 meters deep) due to the limestone bench for up to $1 \mathrm{~km}$ from the shoreline on the western side of island (Fig. 2). Further offshore, the depth increases rapidly. The island is exposed to storms and waves from west and north.

Located $10 \mathrm{~km}$ to the north-east from the island is the fascinating Neugrund bank (Fig. 2). In the 1990s, the nearly circular-shape shoal was recognized as a meteorite impact structure [10]. The buried but partially re-exposed submarine impact structure is an approximately 535 million-year-old meteorite crater with a rim-to-rim diameter of 7-8 km. The water depth at the central plateau is $1-15 \mathrm{~m}$, whereas the adjacent sea depth is $20-40 \mathrm{~m}$ shoreward and $60-70 \mathrm{~m}$ in the circular canyon-like depression to the north. The great number of shipwrecks lying on the seabed testifies to the unusually rugged bottom topography in this region. More than a hundred isolated erratic boulders consisting of brecciated Precambrian metamorphic rock are situated on the seabed and coasts around the structure, including on Osmussaar. In the late 1990s, the mineralogical analysis together with geophysical mapping, seismoacoustic and magnetic profiling served to demonstrate that the Neugrund Bank is a meteorite crater with an initial structural altitude of about $500 \mathrm{~m}$ [10].

The other bank, the Sundgrund to the south-west of the island, is an ordinary shoal, where water depth is about 10 meters. Compared to the Neugrund, it is well exposed to the west and presumably sees stronger wave activity.

\subsection{Geomorphic changes of coasts over the last hundred years}

On the basis of archived descriptions and analysis of positions of previous lighthouse remains at the northern tip of the island, it was established that the Osmussaar scarp is slowly retreating with an average rate of $9 \mathrm{~cm} / \mathrm{yr}$. The $7 \mathrm{~m}$ high limestone scarp is a rather strong obstacle for waves (Fig. 5) and the retreat rate may seem slow, just about 15 meters within last 160 years, but it has still influenced the outline of the lighthouse settlement.

Osmussaar as a whole is slowly migrating to the south-east. The coastline is migrating seaward in the southern half of the island as a result of formation of accumulative beach ridges and spits (Figs. 4, 6). The land is considerably lower and the changes are faster there. The spit in the southern part has grown nearly $800 \mathrm{~m}$ south-eastward in the last century. The former small bay in the southern part of the island became a lake when another spit-like formation closed the entrance into the bay between 1900 and 1935. In addition, the southern coast of the island has migrated over 120 meters southward towards the small bay.

Wind waves (Fig. 5) and sea level variations during occasional storm surges (up to 2-3 m), such as in 1967, 2001, 2005, and 2007, are the main hydrodynamic factors responsible for coastal changes in this part of the nearly tideless Baltic Sea $[11,12]$. It is interesting that while the local mean sea level is still decreasing in most tide gauges around the Osmussaar (Fig. 3a-c), the decrease ranging between zero and $1.1 \mathrm{~mm} / \mathrm{yr}$ is statistically insignificant. Obviously, the regional postglacial uplift $(2.6 \mathrm{~mm} / \mathrm{yr})$ is already roughly 

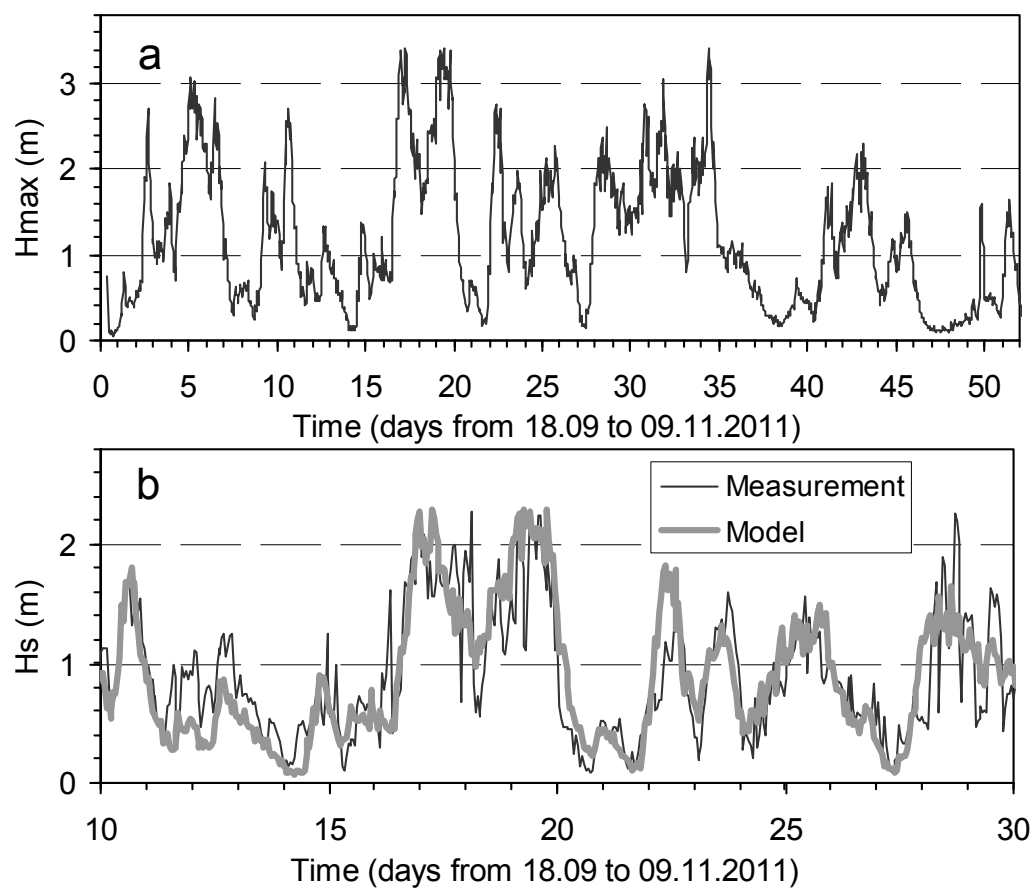

Figure 5: $\quad$ Measured maximum wave heights (a) and calibration of a model for significant wave height (b, excerpt) at Sundgrund in 2011.

balanced out by the global sea level rise. The global rise was probably around $1 \mathrm{~mm} / \mathrm{yr}$ in the 19th century [13], but has accelerated up to 1.7 or even $2 \mathrm{~mm} / \mathrm{yr}$ by the second half of the 20th century [14]. However, the most recent estimates based on satellite altimetry tend to yield even higher values, e.g. up to $3.2 \mathrm{~mm} / \mathrm{yr}$ for a short period 1993-2009 [15]. The second important outcome of Fig. 3 is that, despite land uplift, the annual maximum sea levels are increasing fast (up to $7 \mathrm{~mm} / \mathrm{yr}$ ) in all the tide gauges. This can be explained by the increase in local storminess and in the frequency of westerly winds along the windward coasts of West Estonia [7, 16]. The most rapid changes in Osmussaar have occurred in periods of increased cyclonic and wave activity, the last high phase of which occurred in 1980s-1990s [6, 16]. Map analyses indicate that the processes were twice as rapid during 1982-1998 than in other periods (Fig. 6). Erosion in the proximal part of the spit or former transport zone has increased rapidly since the beginning of the 1980s. Similar tendencies have been observed in other west Estonian coastal study sites as well $[4,12]$.

The rate of coastal change - calculated as a quotient arrived at by dividing the sum of the volume of erosion and accumulation, by the duration of the period measured - increased from $0.3 \mathrm{~m}^{2} /$ year to $2 \mathrm{~m}^{2} /$ year for each meter of shoreline compared to the previous period (1960-1980). Since the beginning of the 1980s, extensive erosion occurred even in the former transport zone. The rate of shore 

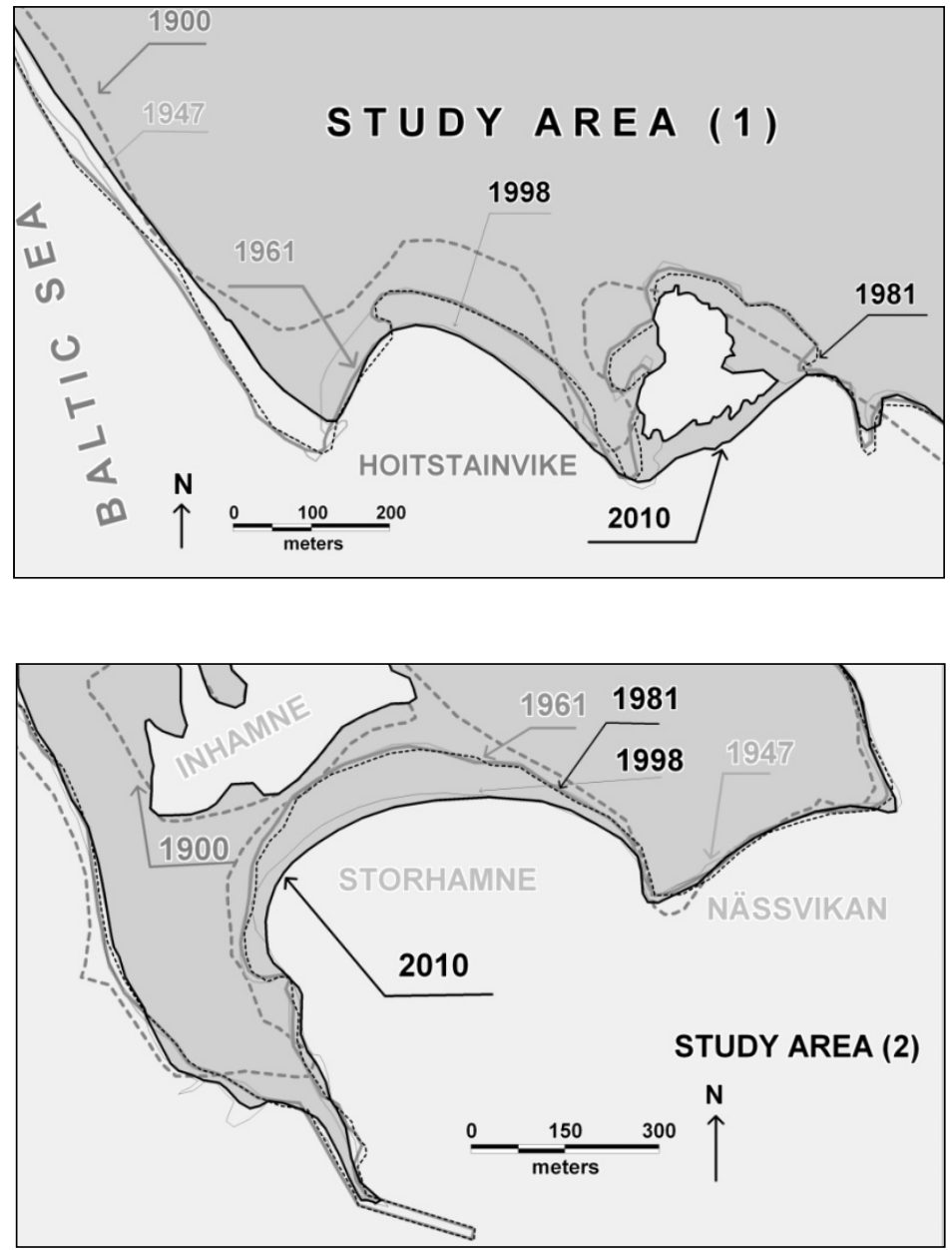

Figure 6: Shoreline changes at the coastal study areas.

changes have decreased during the last decade. However, the rate of changes still exceeds two times the volume of changes measured before the 1980s. Moreover, the share of erosion has reached over $1 / 3$ of total changes.

Although the simple wave model calibration against the measurement was successful (Fig. 5b), the wind input data from the closest (Pakri) meteorological station could be considered as homogeneous for wave hindcast starting just from 2003. Additional hindcasts with more distant but homogeneous input data (e.g. one form Ristna or Lääne-Nigula) should be carried out in the future. Based on preliminary results, the wave activity has decreased at the northerly exposed Neugrund [4], but the frequency of strong wave events have probably increased at westerly exposed coasts [7], including Sundgrund. 


\section{Changes in settlement and landscapes}

\subsection{From the Vikings to the 1930s heyday}

According to the overview by T. Peil [2], the exact colonisation time of the island is unknown, but settlers were mentioned on the island in the fifteenth century. The early settlers mainly came from Gotland, the Stockholm Archipelago and Swedish areas of Finland. A re-settlement of the island from the Estonian mainland areas occurred as well. The island population suffered from several onslaughts of epidemics; for instance the plague epidemic of 1710 was so severe that only a few people reportedly survived. However, re-colonisation quickly occurred and several marriages and children born on the island were recorded in the following years.

The first lighthouse was built on the northern coast of Osmussaar in 1765 . The danger of it falling into the sea became a reality in the mid-nineteenth century. A new lighthouse was built in 1850 and it remained in use until 1941 when the evacuating Soviet garrison demolished the lighthouse settlement. The current $35 \mathrm{~m}$ high lighthouse originates from 1954 and it was reconstructed in 1998 [17]. The second prominent landmark, a chapel on the central part of the island had been initiated by the seafarers in the sixteenth century. The larger stone chapel (Jesu Kapell) was consecrated in 1766.

The sea and the needs of seafaring had a considerable importance on island life [2]. The main part of the island was covered by a sparsely vegetated meadow, which was primarily used as grazing land. Big trees, mainly ashes, were so rare that each had its own name, for example Adam och Eva in the southern part of the island. Generally, all suitable land had been taken under cultivation by the mid-nineteenth century. The locally grown crops (rye, barley, also potato, cabbages) were seldom adequate, and had to be supplemented by imports from the mainland each year. The island hay-fields were small. There was a lack of fodder for the cattle and the milk production was low. Sheep thrived on the island and were important for getting wool and fleece as well as meat; their milk was also used.

Large part of the islanders' livelihood was dependent on the sea and fishing. Nets were used for fishing Baltic herring, flounder, whitefish and sprat.

Cod became important for the island economy just before the Second World War, when cod-liver oil was produced according to the methods acquired from the Lofoten, Norway. The main fishing harbour and net-drying yard was situated on the southern coast. Boats were dragged to the land, but the emergence of bigger ships at the island resulted in the construction of jetties. However, both quays have been destroyed by ice and storms. The islanders reportedly sailed to fetch salt from Sweden during the Crimean War in the 1850s. Another example of early trading was the smuggling of liquor. Two larger boats were jointly built in the 1890s. In 1910, the whole village built a 40-ton-vessel, the Oden, which was wrecked in the 1920s. Three more ships were built this way. The ships were used to transport goods and timber from the mainland to Sweden and Finland. At around 1900, trade with scrap iron originating from shipwrecks started. 
The population of Osmussaar continued to increase through the first decades of the 20th century. The highest recorded population number $(119$, in other sources 131) appears in the census of 1934. A cluster-type village and a lighthouse settlement were located on the island. The subdivision of farms had started in the mid-nineteenth century. Strong blood relations between the farm folks were common and the kinship ties grew more complex with every generation due to the high degree of local endogamy. The school was first founded in 1883, but worked only for ten years then; a second attempt was made in 1910, but due to the poor state of the building and the oncoming war it was soon closed again.

The islanders enjoyed personal freedom and thus had no obligations to the manor on a daily basis. The farmer and his wife were, however, not owners of the farm in the modern sense of the word, since they could not sell it. The islanders never claimed the property right to the island land due to their faith in the continuity of ancient tenure and heritage rights. They succeeded in maintaining their independence until the twentieth century, when the island was sold behind their back to an estate owner in 1903 and resold in 1908. The official owner of Osmussaar paid state taxes, although he never actually lived on the island. He used the island as a base for fishing, but his economic ventures were not successful, since his relations with the islanders were strained. The islanders paid a small tax in fish and salt; this amount was set for the whole island and divided locally.

\subsection{Modern times}

World War II brought profound changes $[2,18]$. The islanders were evacuated to Vormsi on June 12, 1940 when a Soviet military base was established on the island. The islanders were allowed to return in 1942, but the approaching Red Army forced them to leave permanently. First to leave were the young men to escape the German mobilisation. The remaining 46 people left in three boats for Sweden, where the majority of their descendants live now. A Soviet military unit was established on the island.

In general, the contemporary landscape appears as a result of military actions bearing very few traces of the historical settlement or its land use. Most of the bigger boulders that had given the island landscape a lot of its character were ground in a mill and used as a material for cement-making in order to build extensive defence bunkers. The limestone village buildings were demolished for constructing a coastal artillery battery.

To control the entrance to the Gulf of Finland, a battery of three $130 \mathrm{~mm}$ guns, a four barrel $180 \mathrm{~mm}$ (MB-2-180) group and a set of ant-aircraft guns were installed in 1940 [18]. The main $180 \mathrm{~mm}$ long-range cannons were located in 10 $\mathrm{m}$ deep and $7.5 \mathrm{~m}$ diameter fortified mounts. The complexes also included various technical facilities as well as concrete bunkers for gunnery crews. The planned battery of $406 \mathrm{~mm}$ guns was never completed and the original battery was demolished by the end of 1941 before the advancement of the German army. Immediately after World War II there were plans to house a garrison of up to 1200 men on the island, but the large unit was already disbanded in 1947 and 
onwards the island was home to a small Soviet navy and communication unit consisting of a maximum of 40 men.

After Estonia regained its independence, the Soviet army vacated the island in 1993, leaving ruins of military buildings, scrap metal and polluted areas. On March 14, 1996, the Osmussaar Landscape Reserve was established to protect rare and scientifically valuable geological objects and natural communities. The reserve is administrated by the West Estonian Archipelago Biosphere Reserve. Since 2001, one family is permanently residing on the island, whose main task is to herd about 200 Icelandic sheep. The automatized lighthouse does not require permanent surveillance. However, workers employed to restore the chapel and lighthouse or to construct tourist infrastructure episodically reside on the island. Several Estonian tourist companies offer eco-tours, which mostly operate via Port of Dirhami, $9 \mathrm{~km}$ to the southeast. In recent years, about 3000 people have visited the island every summer.

\section{Concluding remarks: climate change and possible future developments}

Climate change in the Baltic Sea area mainly manifests as winter-time temperature rise, but also as sea level rise and increase in local storminess, especially in winter [16]. Although the global sea level rise is projected to accelerate in the 21 st century $[14,19]$, the uncertainty margins are still high. At present, the regional uplift in the Osmussaar area is nearly balanced out by the global sea level rise and from now on projected increasing storminess and sea level acceleration will likely reduce the island. The coastal processes on the westerly exposed coasts are active. The cultural outlook for the future is vague as well. Osmussaar has become a landscape reserve. The islanders never re-gained their ancient rights on land and private enterprises and re-habitation of the island is restricted, but the outlook for eco-tourism is good.

\section{Acknowledgements}

The study was supported by the Estonian Science Foundation grants No. 8549, 8980 and 9191, target financed project SF0180104s08 and the EstKliima project of the European Regional Fund programme No. 3.2.0802.11-0043.

\section{References}

[1] Grant, P.E., (ed.). Evolution on Islands. Oxford University Press: Oxford, 352 pp., 1998.

[2] Peil, T., Settlement history and cultural landscapes on Osmussaar. Estonia Maritima, 4, pp. 5-38, 1999.

[3] Orviku, K., Estonian seacoasts. Valgus: Tallinn, 112 pp., 1974.

[4] Suursaar, Ü., Szava-Kovats, R. and Tõnisson, H., Wave climate and coastal processes in the Osmussaar - Neugrund region, Baltic Sea. 
Coastal processes II. Book Series: WIT Transactions on Ecology and Environment, 149, WIT Press: Southampton, Boston, pp. 99-110, 2011.

[5] USACE - U.S. Army Coastal Engineering Research Center, Shore Protection Manual, Vol.1, Third Ed., U.S. Govt. Printing Office, Washington D.C., 719 pp, 1984.

[6] Suursaar, Ü. and Kullas, T., Decadal variations in wave heights off Kelba, Saaremaa Island, and their relationships with changes in wind climate. Oceanologia, 51, pp. 39-61, 2009.

[7] Suursaar, Ü., Waves, currents and sea level variations along the Letipea Sillamäe coastal section of the southern Gulf of Finland. Oceanologia, 52 pp. 391-416, 2010.

[8] Suuroja, K., Saadre, T. and Kask, J., Geology of Osmussaar Island. Estonia Maritima, 4, pp. 39-65, 1999.

[9] Vallner, L., Sildvee, H. and Torim, A., Recent crustal movements in Estonia. J. Geodyn., 9, pp. 215-223, 1988.

[10] Suuroja, K. and Suuroja, S., Neugrund structure - a submarine meteorite crater at the entrance to the Gulf of Finland. Estonia Maritima, 4, pp. 161-189, 1999.

[11] Suursaar, Ü., Kullas, T., Otsmann, M., Saaremäe, I., Kuik, J. and Merilain, M., Cyclone Gudrun in January 2005 and modelling its hydrodynamic consequences in the Estonian coastal waters. Boreal Environment Research, 11, pp. 143-159, 2006.

[12] Tõnisson, H., Orviku, K., Jaagus, J., Suursaar, Ü., Kont, A. and Rivis, R., Coastal Damages on Saaremaa Island, Estonia, Caused by the Extreme Storm and Flooding on January 9, 2005. Journal of Coastal Research, 24, pp. 602-614, 2008.

[13] Ekman, M., Climate changes detected through the world's longest sea level series. Global and Planetary Change, 21, pp. 215-224, 1999.

[14] Church, J.A. and White, N.J., A 20th century acceleration in global sea level rise. Geophysical Research Letters, 33, L01602, doi: 10.1029/2005GL024826, 2006.

[15] Church, J.A. and White, N.J., Sea-level rise from the late 19th to the early 21 st century. Surveys in Geophysics, 32, pp. 585-602, 2011.

[16] Jaagus, J., Post, P. and Tomingas, O., Changes in storminess on the western coast of Estonia in relation to large-scale atmospheric circulation. Climate Research, 36, pp. 29-40, 2008.

[17] Aleksejev, I., Estonian lighthouses. GT Projekt: Tallinn, 119 pp., 2003. [in Estonian].

[18] Ojaste, H., Ojaste, I., Randla, T. and Keskpaik, T., (eds.). Osmussaar: nature, settlement. Silma Looduskaitseala administratsioon: Noarootsi, 48 pp., 2002. [in Estonian].

[19] Kont, A., Endjärv, E., Jaagus, J., Lode, E., Orviku, K., Ratas, U., Rivis, R., Suursaar, Ü. and Tõnisson, H., Impact of climate change on Estonian coastal and inland wetlands - a summary with new results. Boreal Environment Research, 12, pp. 653-671, 2007. 